Article

\title{
Cytotoxic Compounds from Juglans sinensis Dode Display Anti-Proliferative Activity by Inducing Apoptosis in Human Cancer Cells
}

\author{
Yoo Jin Lee ${ }^{1,+}{ }^{\dagger}$ Jun Cui ${ }^{2,+}{ }^{,}$Jun Lee ${ }^{3,4}$, Ah-Reum Han ${ }^{1}$, Eun Byul Lee ${ }^{2}$, Ho Hee Jang ${ }^{2,5, *}$ and \\ Eun Kyoung Seo ${ }^{1, *}$ \\ Received: 18 November 2015 ; Accepted: 14 January 2016 ; Published: 21 January 2016 \\ Academic Editors: Derek J. McPhee and John A. Beutler \\ 1 College of Pharmacy, Graduate School of Pharmaceutical Sciences, Ewha Womans University, \\ Seoul 120-750, Korea; yoojin0909@hanmail.net (Y.J.L.); andyhanandy@naver.com (A.-R.H.) \\ 2 Department of Molecular Medicine, Graduate School of Medicine, Lee Gil Ya Cancer and Diabetes Institute, \\ Gachon University, Incheon 406-840, Korea; cuijun928@naver.com (J.C.); jojnstar@naver.com (E.B.L.) \\ 3 KM Convergence Research Division, Korea Institute of Oriental Medicine, Daejeon 34054, Korea; \\ junlee@kiom.re.kr \\ 4 Korean Medicine Life Science, University of Science \& Technology, Daejeon 34054, Korea \\ 5 Gachon Medical Research Institute, Gil Hospital, Incheon 405-760, Korea \\ * Correspondence: hhjang@gachon.ac.kr (H.H.J.); yuny@ewha.ac.kr (E.K.S.); Tel.: +82-2-3277-3047 (E.K.S.); \\ Fax: +82-2-3277-3051 (E.K.S.) \\ + These authors contributed equally to this work.
}

\begin{abstract}
Phytochemical investigation of the bark of Juglans sinensis Dode (Juglandaceae) led to the isolation of two active compounds, 8-hydroxy-2-methoxy-1,4-naphthoquinone (1) and 5-hydroxy-2-methoxy-1,4-naphthoquinone (2), together with 15 known compounds 3-17. All compounds were isolated from this plant for the first time. The structures of $\mathbf{1}$ and $\mathbf{2}$ were elucidated by spectroscopic data analysis, including 1D and 2D NMR experiments. Compounds 1-17 were tested for their cytotoxicity against the A549 human lung cancer cell line; compounds $\mathbf{1}$ and $\mathbf{2}$ exhibited significant cytotoxicity and additionally had potent cytotoxicity against six human cancer cell lines, MCF7 (breast cancer), SNU423 (liver cancer), SH-SY5Y (neuroblastoma), HeLa (cervical cancer), HCT116 (colorectal cancer), and A549 (lung cancer). In particular, breast, colon, and lung cancer cells were more sensitive to the treatment using compound $\mathbf{1}$. In addition, compounds $\mathbf{1}$ and $\mathbf{2}$ showed strong cytotoxic activity towards human breast cancer cells MCF7, HS578T, and T47D, but not towards MCF10A normal-like breast cells. They also inhibited the colony formation of MCF7, A549, and HCT116 cells in a dose-dependent manner. Flow cytometry analysis revealed that the percentage of apoptotic cells significantly increased in MCF7 cells upon the treatment with compounds $\mathbf{1}$ and $\mathbf{2}$. The mechanism of cell death caused by compounds 1 and $\mathbf{2}$ may be attributed to the upregulation of Bax and downregulation of $\mathrm{Bcl} 2$. These findings suggest that compounds $\mathbf{1}$ and $\mathbf{2}$ may be regarded as potential therapeutic agents against cancer.
\end{abstract}

Keywords: Juglans sinensis Dode; Juglandaceae; 8-hydroxy-2-methoxy-1,4-naphthoquinone; 5-hydroxy-2-methoxy-1,4-naphthoquinone; cytotoxicity; antiproliferative activity; apoptosis

\section{Introduction}

Juglans sinensis Dode (Juglandaceae) is a deciduous tree indigenous to Eastern Asia and commonly known as the walnut tree. Previous phytochemical reports on this plant identified terpenoids, diarylheptanoids, naphthalenones, flavonoids, and phenolic compounds [1-4], which were related to its cytotoxic [1], neuroprotective [2], hepatic fibrosis inhibitory [3], and hepatoprotective [4] activities. 
The extracts of J. sinensis show antiasthma effects [5] and antioxidant activities on liver damage [6] and acute renal failure [7].

In previous reports on the anticancer effects of Juglans species, the extracts of root barks, fruits, or seeds of J. regia showed anti-proliferative activity against Caco-2 human colon cancer cells, HepG2 human liver cancer cells, and MDA-MB-231 human breast cancer cells [8-10]; the extract of seeds of J. sinensis protected UVB-induced human keratinocytes apoptosis [11]. Sesquiterpenes and triterpenes isolated from the leaves and twigs of $J$. sinensis inhibited the proliferation of immortalized rat hepatic stellate cells through apoptosis [1]; however, the mechanism of action of the anti-proliferation activity of the phenolic compounds of $J$. sinensis has not been investigated in detail.

Therefore, in continuation of our search for novel natural anticancer agents, we performed a bioactivity-guided fractionation to isolate and identify cytotoxic compound(s) from J. sinensis. Herein, we describe the separation and structure elucidation of such cytotoxic compounds, and furthermore, we evaluated their anti-proliferative and apoptotic activity to study mechanism of the cytotoxicity of these compounds in human cancer cells.

\section{Results and Discussion}

\subsection{Phytochemical Characterization of the Bark of J. sinensis}

The structures of compounds $\mathbf{1}$ and $\mathbf{2}$ were identified by spectroscopic data interpretation (Figure 1). Compound $\mathbf{1}$ was obtained as a light brown powder. It gave a molecular ion peak at $m / z 204.0421[\mathrm{M}]^{+}$(calcd. for $\mathrm{C}_{11} \mathrm{H}_{8} \mathrm{O}_{4}{ }^{+}, 204.0423$ ) in HRESIMS, corresponding to an elemental formula of $\mathrm{C}_{11} \mathrm{H}_{8} \mathrm{O}_{4}$. The UV spectrum of 1 showed an absorption maximum at $263 \mathrm{~nm}$, indicating the presence of an aromatic system. The ${ }^{1} \mathrm{H}-\mathrm{NMR}$ spectrum of $\mathbf{1}$ showed signals for a hydroxy group at $\delta_{\mathrm{H}} 11.75(1 \mathrm{H}, \mathrm{s})$, an aromatic ring system at $\delta_{\mathrm{H}} 7.25(1 \mathrm{H}, \mathrm{dd}, J=2.8,6.4 \mathrm{~Hz})$ and 7.63 (overlapped $2 \mathrm{H}, \mathrm{d}, J=2.8,6.4 \mathrm{~Hz})$, an aromatic singlet at $\delta_{\mathrm{H}} 6.11(1 \mathrm{H}, \mathrm{s})$, and a methoxy group at $\delta_{\mathrm{H}} 3.92(3 \mathrm{H}, \mathrm{s})$. The ${ }^{13} \mathrm{C}$-NMR spectrum of 1 showed signals for two carbonyls at $\delta_{\mathrm{C}} 184.9$ (C-1) and 183.9 (C-4), two oxygenated quaternary carbons at $\delta_{C} 162.0(\mathrm{C}-8)$ and $160.1(\mathrm{C}-2)$, four aromatic methines at $\delta_{C} 137.2$ (C-6), 123.9 (C-7), 118.9 (C-5), and 110.5 (C-3), and two quaternary carbon signals at $\delta_{C} 132.1$ (C-10) and 114.3 (C-9). These spectral data supported the notion that compound 1 contained a naphthalenedione, as evidenced by the HMBC correlations of H-3/C-1, C-2, C-10, H-5 and H-6 (overlapped peak)/C-4, C-6, $\mathrm{C}-7, \mathrm{C}-9, \mathrm{C}-10, \mathrm{H}-7 / \mathrm{C}-6, \mathrm{C}-9$. The positions of the hydroxyl group at C-8 and the methoxy group at C-2 were confirmed by the $\mathrm{HMBC}$ correlations of $\mathrm{O} \underline{\mathrm{H}} / \mathrm{C}-7, \mathrm{C}-8, \mathrm{C}-9$ and $\mathrm{OC}_{3} / \mathrm{C}-2$, respectively (Figure 2). Based on these observations and by comparison of its spectral data with literature values [12,13], compound 1 was identified as 8-hydroxy-2-methoxy-1,4-naphthoquinone (Figure 1).

Compound 2 was obtained as a light brown powder and showed a molecular ion peak at $\mathrm{m} / \mathrm{z}$ $204.0421[\mathrm{M}]^{+}$(calcd. for $\mathrm{C}_{11} \mathrm{H}_{8} \mathrm{O}_{4}{ }^{+}, 204.0423$ ) in HRESIMS, corresponding to an elemental formula of $\mathrm{C}_{11} \mathrm{H}_{8} \mathrm{O}_{4}$. The ${ }^{1} \mathrm{H}$ - and ${ }^{13} \mathrm{C}-\mathrm{NMR}$ spectra of 2 were similar to those of $\mathbf{1}$, except for the signals of the aromatic ring system. The ${ }^{1} \mathrm{H}-\mathrm{NMR}$ spectrum of 2 showed an aromatic ring system at $\delta_{\mathrm{H}} 7.28$ $(1 \mathrm{H}, \mathrm{dd}, J=1.2,8.1 \mathrm{~Hz}), 7.59(1 \mathrm{H}, \mathrm{t}, J=8.1 \mathrm{~Hz}), 7.68(1 \mathrm{H}, \mathrm{dd}, J=1.2,8.1 \mathrm{~Hz})$. The positions of the hydroxyl group at $\mathrm{C}-5$ and the methoxy group at $\mathrm{C}-2$ were confirmed by the HMBC correlations of $\mathrm{OH} / \mathrm{C}-5, \mathrm{C}-6, \mathrm{C}-10$ and $\mathrm{OCH}_{3} / \mathrm{C}-2$, respectively (Figure 2). Therefore, compound 2 was identified as 5-hydroxy-2-methoxy-1,4-naphthoquinone (Figure 1) by comparison of its spectral data with literature values [14].

The known compounds identified in the present investigation are as follows: (4S)-isosclerone (3) $[15,16],(4 S)-5$-hydroxy-4-methoxy- $\alpha$-tetralone (4) [16], juglonbutine (5) [17], (2S)-sakuranetin (6) [18-20], (2S)-naringenin (7) [19-21], (2R)-sakuranin (8) [19,20,22], kaempferol (9) [22], quercetin (10) [23], quercitrin (11) [24], afzelin (12) [24], (-)-taxifolin 3-O- $\alpha$-L-arabinofuranoside (13) [25], (erythro)-1-(4-hydroxyphenyl)-1,2,3-propanetriol (14) [26], 4'-hydroxy-2', 6'-dimethoxyphenol 1-O- $\beta$-D-(6-O-syringoyl) glucopyranoside (15) [27], (7S,8S)-cilicione b (16) [28], and (2R)-1,2-butanediol (17) [29] by comparison of their physical and spectroscopic data with the literature data (Figure 1). 
These compounds 3-17 were all isolated as the constituents of this plant for the first time. Moreover, $\mathbf{1 4}$ and $\mathbf{1 6}$ have not been found in the family Juglandaceae.<smiles>COC1=CC(=O)c2cccc(O)c2C1=O</smiles><smiles>COC1=CC(=O)c2c(O)cccc2C1=O</smiles><smiles>O=C1CC[C@H](O)c2cccc(O)c21</smiles><smiles>CO[C@H]1CCC(=O)c2cccc(O)c21</smiles><smiles>O=C(O)CCCCNC1=CC(=O)c2c(O)cccc2C1=O</smiles><smiles>O=C1CC(c2ccc(O)cc2)Oc2cc(Br)cc(O)c21</smiles>
$\begin{array}{lc}\mathbf{2} 1 \\ \mathbf{O} & \mathrm{OCH}_{3} \\ \mathrm{OH}\end{array}$<smiles>COc1cc(O)c2c(c1)OC(c1ccc(O)cc1)CC2=O</smiles><smiles>C=CCC#CC#CCO</smiles>

$\begin{array}{ccc} & \text { R1 } \\ \text { 9 } & \mathrm{H} \\ 10 & \mathrm{H} \\ 11 & \alpha-R h a \\ 12 & \alpha-\text { Rha }\end{array}$<smiles>CCCO[C@H]1C(=O)c2c(O)cccc2O[C@H]1c1ccc(O)c(O)c1</smiles>

13<smiles>CCC(O)CO</smiles>

16

Figure 1. Chemical structures of the isolates 1-17 from the bark of J. sinensis.

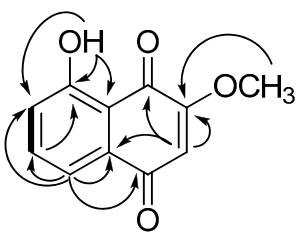

1

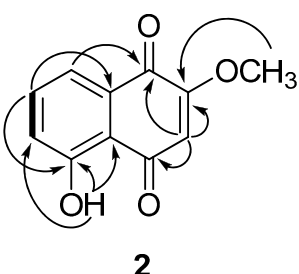

2

Figure 2. Key COSY (-) and $\operatorname{HMBC}(\rightarrow)$ correlations of $\mathbf{1}$ and $\mathbf{2}$.

\subsection{Biological Evaluations of Compounds}

\subsubsection{Identification of Cytotoxic Compounds}

The cytotoxic activities of the $\mathrm{MeOH}$ extract, solvent-partitioned fractions, and the compounds isolated from J. sinensis were examined on the A549 human non-small cell lung cancer cell line at various concentrations for $24 \mathrm{~h}$. Inhibitory concentration $\left(\mathrm{IC}_{50}\right)$ values were calculated from their cell viability curves. Because the $\mathrm{MeOH}$ extract showed cytotoxic activity against A549 cells, this extract was partitioned into hexane, ethyl acetate, butanol, and aqueous soluble fractions. As shown in Table 1, the ethyl acetate fraction was the major fraction responsible for the cytotoxic activity compared to other fractions.

Individual compounds were isolated from the ethyl acetate fraction, and their $\mathrm{IC}_{50}$ values were determined against A549 cells. The cells were treated with 0-50 $\mu \mathrm{M}$ of compounds 1 to 17 for $24 \mathrm{~h}$. Compounds 1 and 2 showed strong cytotoxicity against A549 cells, with the $\mathrm{IC}_{50}$ values of 1.82 and $1.33 \mu \mathrm{M}$, respectively, whereas other compounds were inactive $\left(\mathrm{IC}_{50}>10 \mu \mathrm{M}\right.$, Table 1$)$. Based on the cytotoxic potency and selectivity, compounds $\mathbf{1}$ and $\mathbf{2}$ were selected as the potential anticancer compounds and for further investigation of their cytotoxicity against different human cancer cell lines. 
Table 1. Cytotoxicity of the extract, fractions, and compounds isolated from J. sinensis.

\begin{tabular}{cc}
\hline Samples & IC $_{\mathbf{5 0}}$ \\
\hline Methanol extract & $153.4 \pm 10.61^{\mathrm{a}}$ \\
Hexane fraction & $41.92 \pm 3.68^{\mathrm{a}}$ \\
Ethyl acetate fraction & $31.23 \pm 0.67^{\mathrm{a}}$ \\
Butanol fraction & $61.51 \pm 2.00^{\mathrm{a}}$ \\
Aqueous fraction & $155.3 \pm 10.71^{\mathrm{a}}$ \\
$\mathbf{1}$ & $1.33^{\mathrm{b}}$ \\
$\mathbf{2}$ & $1.82^{\mathrm{b}}$ \\
$\mathbf{3 - 1 7}$ & $>10^{\mathrm{b}}$ \\
\hline
\end{tabular}

\subsubsection{Cytotoxic Effects of Compounds 1 and $\mathbf{2}$ against Various Human Cancer Cells}

Different human cancer cell lines were treated with compounds $\mathbf{1}$ and $\mathbf{2}$ using serial dilution concentrations $(10,5,2.5,1.25,0.625$, and $0 \mu \mathrm{M})$. As shown in Figure 3, the cell viability rates decreased with increasing concentrations of compounds $\mathbf{1}$ and $\mathbf{2}$ in a dose-dependent manner. Compound $\mathbf{1}$ showed significant cytotoxic activity for all the cancer cells tested (MCF7, SNU423, SH-SY5Y, HeLa, HCT116, and A549), with $\mathrm{IC}_{50}$ values of $1.95 \pm 0.05,10.87 \pm 0.33,4.13 \pm 0.27,4.07 \pm 0.06,1.83 \pm 0.12$, and $1.33 \pm 0.02 \mu \mathrm{M}$, respectively (Table 2 and Figure $4 \mathrm{~A}$ ). Similarly, compound 2 demonstrated potent cytotoxicity against all six cancer cells (MCF7, SNU423, SH-SY5Y, HeLa, HCT116, and A549), with $\mathrm{IC}_{50}$ values of $1.96 \pm 0.04,10.42 \pm 0.31,6.07 \pm 0.05,3.70 \pm 0.05,3.00 \pm 0.12$, and $1.82 \pm 0.03 \mu \mathrm{M}$, respectively (Table 2 and Figure 4A). Especially, compound 1 displayed strong activity against MCF7 breast cancer, HCT116 colon cancer, and A549 lung cancer cells. A549 and MCF7 cells were used to further evaluate the cytotoxic effect of compounds $\mathbf{1}$ and $\mathbf{2}$. In addition, when compounds $\mathbf{1}$ or $\mathbf{2}$ were treated in A549 and MCF7 cells for $24 \mathrm{~h}$, the cell morphology became more round and floated compared to the untreated healthy cells, showing a dissimilar cytoskeleton (Figure 4B).
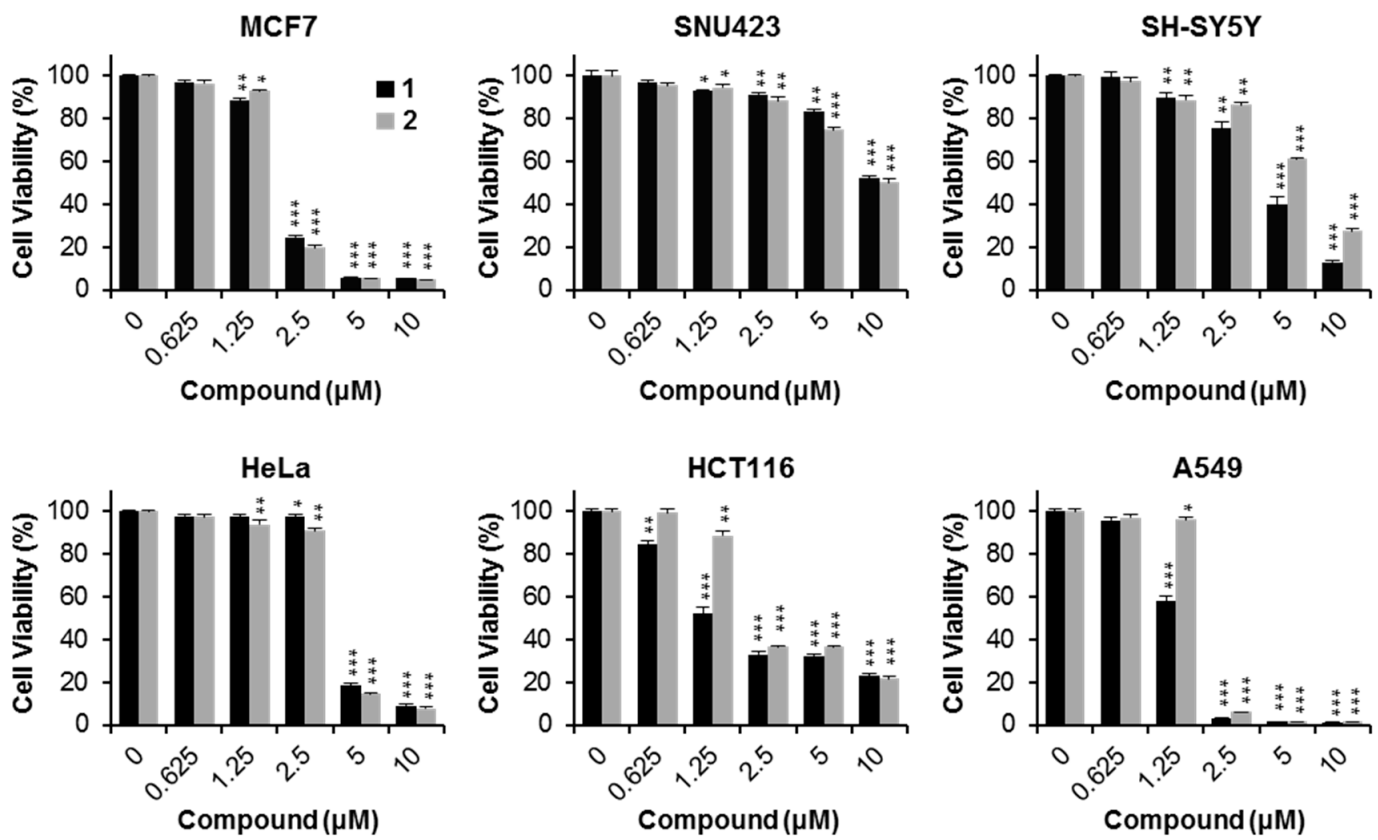

Figure 3. Cytotoxicity of compounds $\mathbf{1}$ and $\mathbf{2}$ on human cancer cell lines. Cells were treated with compounds 1 and 2 at the indicated concentration for $24 \mathrm{~h}$. Cytotoxicity was evaluated by the cell viability assay. ${ }^{*} p<0.05 ;{ }^{* *} p<0.01 ;{ }^{* * *} p<0.001$, compared to the control. 
Table 2. $\mathrm{IC}_{50}$ values $(\mu \mathrm{M})$ of compounds 1 and 2 against human cancer cell lines.

\begin{tabular}{ccccccc}
\hline Compounds & MCF7 & SNU423 & SH-SY5Y & HeLa & HCT116 & A549 \\
\hline $\mathbf{1}$ & $1.95 \pm 0.05$ & $10.87 \pm 0.33$ & $4.13 \pm 0.27$ & $4.07 \pm 0.06$ & $1.83 \pm 0.12$ & $1.33 \pm 0.02$ \\
$\mathbf{2}$ & $1.96 \pm 0.04$ & $10.42 \pm 0.31$ & $6.07 \pm 0.05$ & $3.70 \pm 0.05$ & $3.00 \pm 0.12$ & $1.82 \pm 0.03$ \\
\hline \multicolumn{7}{c}{ The data are expressed as mean + SD of three independent experiments. }
\end{tabular}

(A)

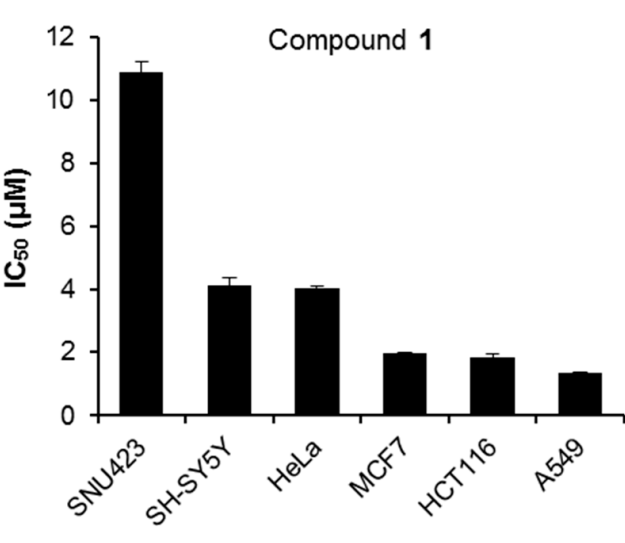

Cell lines

(B)
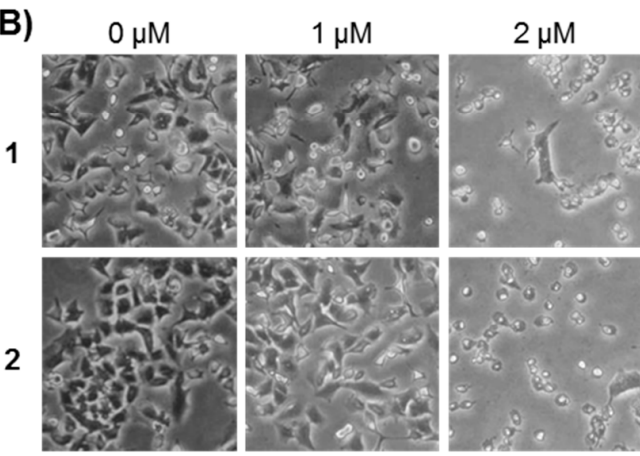

A549

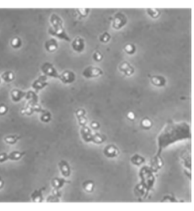

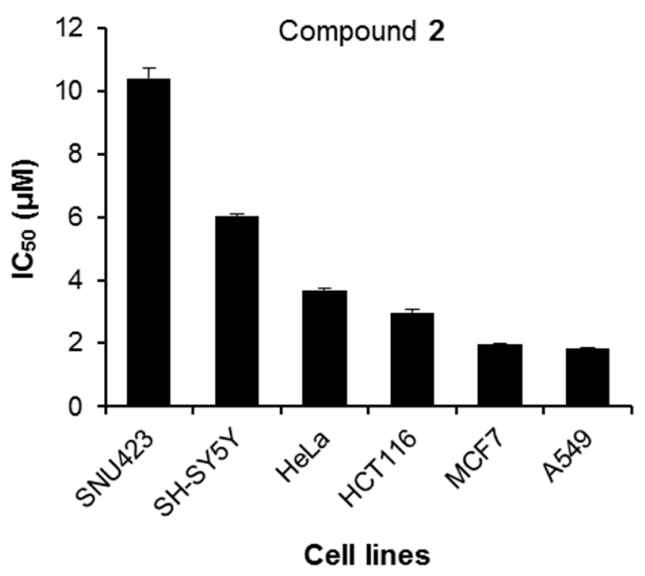

1
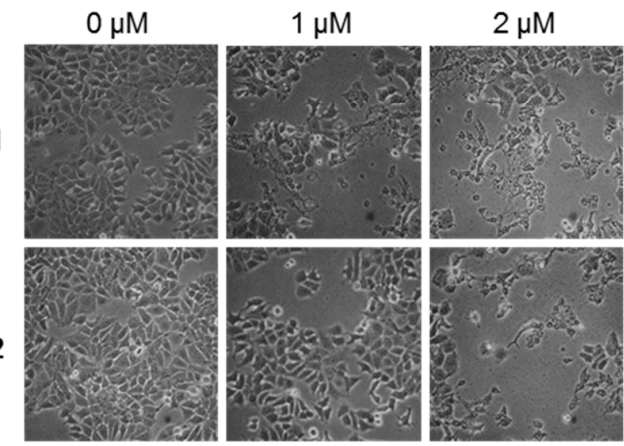

MCF7

Figure 4. $\mathrm{IC}_{50}$ values of compounds 1 and 2 against human cancer cell lines. (A) The $\mathrm{IC}_{50}$ values of compounds 1 and 2 for indicated cell lines; (B) Cell morphology of A549 and MCF7 cells treated with compounds 1 and 2 for 24 h under microscopic observation $(400 \times)$.

\subsubsection{Cancer Cell Specific Cytotoxicity of Compounds $\mathbf{1}$ and $\mathbf{2}$}

To examine whether compounds $\mathbf{1}$ and $\mathbf{2}$ inducesd cancer cell specific cytotoxicity, human normal mammary epithelial cells (MCF10A) and breast cancer cell lines (MCF7, Hs578T, T47D) were treated with $2.5 \mu \mathrm{M}$ of compounds 1 and 2 for $24 \mathrm{~h}$. As shown in Figure 5, the cell viability of compound 1- or 2-treated MCF10A cells was $87.83 \% \pm 0.94 \%$ and $80.45 \% \pm 0.69 \%$, respectively. However, the cytotoxic effect of compounds $\mathbf{1}$ and $\mathbf{2}$ was higher in the breast cancer cells than in normal-like breast cells. Cell viability of T47D, Hs578T and MCF7 treated with compound 1 was $49.50 \% \pm 0.76 \%$, $31.40 \% \pm 0.56 \%$, and $24.54 \% \pm 1.08 \%$, respectively. Cell viability of T47D, Hs578T, and MCF7 cells treated with compound 2 was $60.29 \% \pm 1.21 \%, 59.39 \% \pm 0.31 \%$, and $19.89 \% \pm 1.10 \%$, respectively. These findings indicate that compounds $\mathbf{1}$ and $\mathbf{2}$ displayed significant cytotoxicity to human breast cancer cells. 


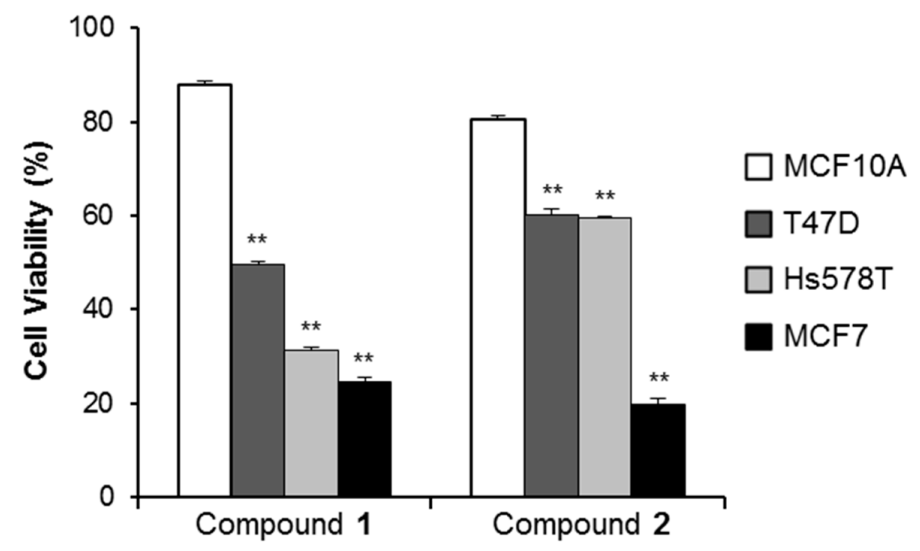

Figure 5. Cytotoxic effects in the normal and breast cancer cell lines. Cells were exposed to $2.5 \mu \mathrm{M}$ of compounds 1 and 2 for 24 h. ${ }^{* *} p<0.01$, compared to the MCF10A cells. Data presented are mean \pm SD from three independent observations.

\subsubsection{Anti-Proliferative Activity of Compounds $\mathbf{1}$ and $\mathbf{2}$}

To explore the anticancer properties of compounds $\mathbf{1}$ and 2, colony formation assays were performed. MCF7 cells were incubated with compounds 1 and 2 at various concentrations $(0,0.5$, 1 , and $2 \mu \mathrm{M}$ ) for two weeks. Compounds 1 and 2 suppressed the colony formation of MCF7 breast cancer cells in a dose-dependent manner, and compound $\mathbf{1}$ was more sensitive than compound $\mathbf{2}$ for MCF7 cells (Figure 6A). To further confirm these results, the inhibitory effect of colony formation was also examined using another two cell lines, HCT116 colon cancer cells and A549 lung cancer cells, at the same concentrations of compounds $\mathbf{1}$ and $\mathbf{2}$ (Figure $6 \mathrm{~B}, \mathrm{C}$ ). The results show that compounds $\mathbf{1}$ and $\mathbf{2}$ can inhibit the colony formation capacity; especially compound $\mathbf{1}$ was also more sensitive than compound 2 for both A549 and HCT116 cells, which was consistent with that of MCF7 cells. Taken together, compounds $\mathbf{1}$ and $\mathbf{2}$ showed the inhibitory effect of the colony formation in human cancer cells, and compound 1 was more sensitive than compound $\mathbf{2}$ for human cancer cells.

(A)

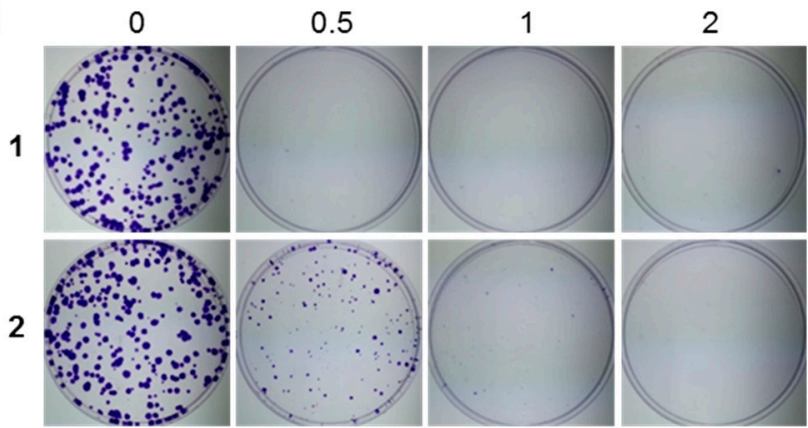

(B)

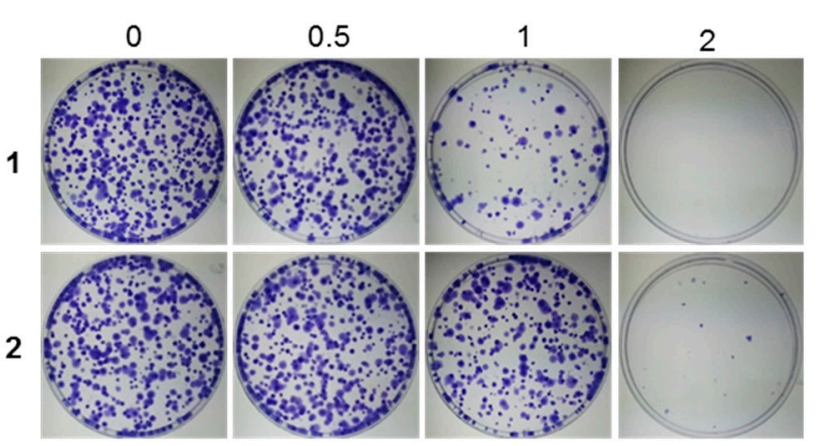

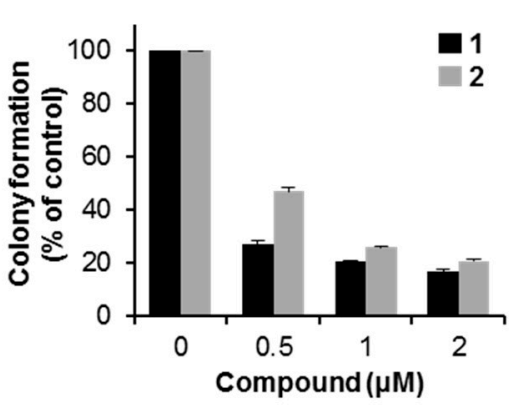

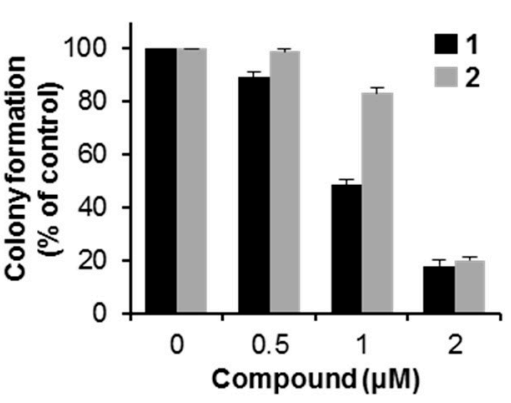

Figure 6. Cont. 
(C)

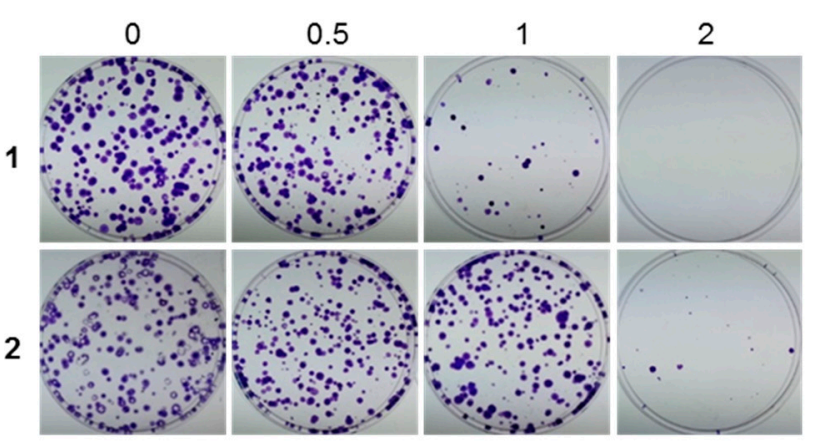

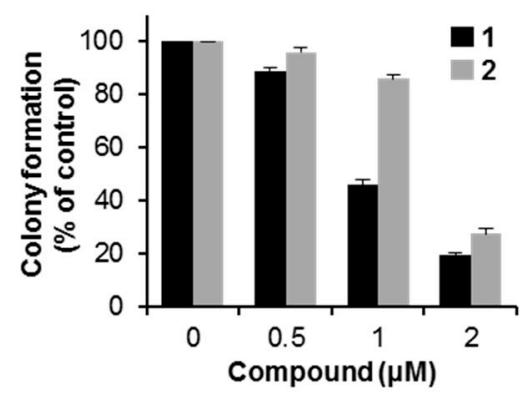

Figure 6. Inhibitory effects of compounds $\mathbf{1}$ and $\mathbf{2}$ on colony formation capacity of human cancer cells. The colony formation assays of MCF7 (A); A549 (B); and HCT116 cells (C) treated with compounds $\mathbf{1}$ and $\mathbf{2}$ at the indicated concentrations for two weeks. Data presented are mean \pm SD from three independent observations.

\subsubsection{Apoptotic Activity of Compounds $\mathbf{1}$ and $\mathbf{2}$}

To determine whether compounds $\mathbf{1}$ and $\mathbf{2}$ caused apoptosis, flow cytometry was performed using Annexin V-FITC and propidium iodide (PI) double staining assay in MCF7 cells. At $24 \mathrm{~h}$ after treatment with $\mathbf{1}$ and $\mathbf{2}$, the proportion of apoptotic cells was $61 \%$ higher in $2 \mu \mathrm{M}$ compound 1-treated MCF7 cells than in the control cells $(72.19 \% \pm 0.36 \%$ vs. $10.79 \% \pm 0.19 \%, p<0.01)$ and $76 \%$ higher in $2 \mu \mathrm{M}$ compound 2-treated MCF7 cells than in the control cells $(87.02 \% \pm 0.18 \%$ vs. $11.04 \% \pm 0.26 \%$, $p<0.01$ ) (Figure 7A).
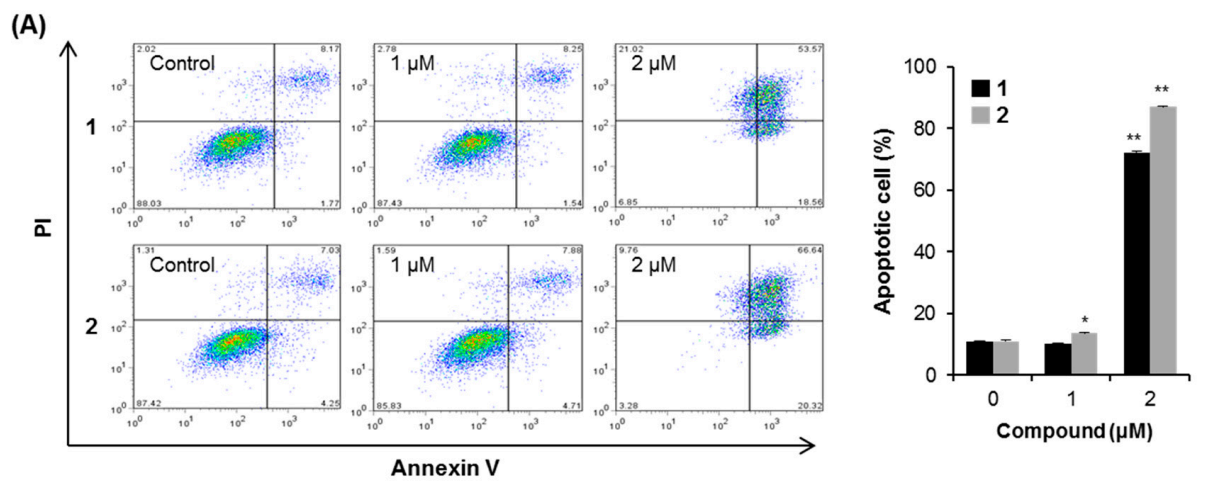

(B)
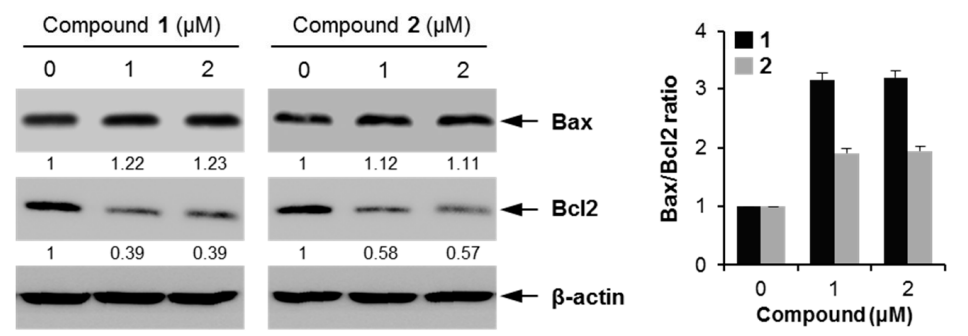

Figure 7. Cellular apoptosis by compounds $\mathbf{1}$ and $\mathbf{2}$ in MCF7 cells. (A) Flow cytometry was performed to measure cellular apoptosis. ${ }^{*} p<0.05 ;{ }^{* *} p<0.01$ vs. control; (B) western blot was performed using the indicated antibodies. The numbers represent the mean fold change of the respective protein levels in compounds-treated cells relative to the control cells. The Bax/Bcl2 ratio is shown as fold changes compared to that of the untreated cells.

Moreover, compound 1 induced cell necrosis at $2 \mu \mathrm{M}$ compared to the untreated control group $(2.02 \% \pm 0.62 \%$ vs. $21.02 \% \pm 1.12 \%)$; however, compound 2 did not induce cell necrosis (Figure 7A). These findings indicate that compounds 1 and 2 could induce apoptosis and inhibit cancer cell 
growth. To study the mechanism of compounds $\mathbf{1}$ and 2 -induced apoptosis, the expression levels of apoptosis-related proteins were measured using western blotting (Figure 7B). The treatment with these compounds increased the expression level of Bax, a pro-apoptotic protein, whereas the expression level of $\mathrm{Bcl} 2$, an anti-apoptotic protein, decreased by the treatment with these compounds. When the expression level of Bax was represented as ratios to the level of Bcl2, the treatment with these compounds increased the ratio of $\mathrm{Bax} / \mathrm{Bcl} 2$, and especially a significant elevation in the ratio of $\mathrm{Bax} / \mathrm{Bcl} 2$ in compound 1-treated cells was observed. Altogether, these findings demonstrate that compounds 1 and $\mathbf{2}$ induced apoptosis by regulating pro- and anti-apoptotic genes.

\subsection{Discussion}

Breast cancer is the second most common reason for death in females worldwide [30]. In this study, 17 phenolic compounds 1-17 were isolated from the bark of J. sinensis; their cytotoxic activities were tested against diverse human cancer cells. Among them, compounds $\mathbf{1}$ and $\mathbf{2}$ exhibited cytotoxic activities and inhibited human cancer cell growth, which was in agreement with the previous reporters for similar compounds [31-33].

2-Methoxy-1,4-naphthoquinone (MNQ) exerts anticancer activity by the induction of apoptosis [34]. Our data demonstrate that compounds 1 and $\mathbf{2}$ induced apoptotic characteristics such as cytoplasm retraction, bleb formation, and the condensation of nuclear material [35,36], in a dose-dependent manner (Figure 4B). Identified apoptotic pathways in cells can divide into two pathways mediated by: (i) the death receptor and (ii) mitochondria [37,38]. Recent report showed that MNQ promotes cancer cell death by a reactive oxygen species (ROS)-dependent mechanism [34]. Since compounds $\mathbf{1}$ and $\mathbf{2}$ have the same skeleton as MNQ, compounds $\mathbf{1}$ and $\mathbf{2}$ should have similar activity as MNQ based on their structures. The mitochondrial-mediated apoptosis is regulated by the Bcl2 protein family [39]. Pro-apoptotic protein Bax transposes to the mitochondrial outer membrane, and anti-apoptotic protein Bcl2 expression decreases followed by cytochrome c release inducing cell apoptosis. Our results show that compounds $\mathbf{1}$ and $\mathbf{2}$ induced cell apoptosis by reducing Bcl2 protein and increasing Bax protein, therefore they may induce cell apoptosis by a mitochondrial-mediated pathway.

\section{Experimental Section}

\subsection{General Procedures}

Optical rotations were measured on a P-1010 polarimeter (Jasco, Tokyo, Japan). UV spectra were recorded on a U-3000 spectrophotometer (Hitachi, Tokyo, Japan). CD spectra were obtained using a J-810 CD-ORD spectropolarimeter (Jasco). HR-ESI mass spectrometric analyses were performed with an ACQUITY UPLC system (Waters Co., Milford, MA, USA) coupled to a Micromass Q-TOF Micromass spectrometer and a 6220 Accurate-Mass TOF LC/MS system (Agilent Technologies, Inc., Santa Clara, CA, USA). The 1D and 2D NMR experiments were performed on a Unity Inova $400 \mathrm{MHz}$ FT-NMR instrument (Varian, Inc., Palo Alto, CA, USA) with tetramethylsilane (TMS) as an internal standard. Thin-layer chromatographic (TLC) analysis was performed on Kieselgel $60 \mathrm{~F}_{254}$ (Merck, Darmstadt, Germany), with visualization under UV light (254 and $365 \mathrm{~nm})$ and 10\% (v/v) sulfuric acid spray followed by heating

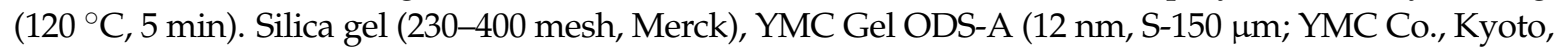
Japan), and Sephadex LH-20 (Pharmacia Co., Uppsala, Sweden) were used for column chromatography (CC). (Please provide us the full information of company, city, country for all the equipment).

\subsection{Materials and Chemicals}

The barks of J. sinensis were collected at the Medicinal Plant Garden, College of Pharmacy, Ewha Womans University, in August 2010, and identified by Prof. Je-Hyun Lee (Dongguk University, Geongju 780-714, Korea). A voucher specimen (No. EA310) was deposited at the Natural Product Chemistry Laboratory, College of Pharmacy, Ewha Womans University. Cell culture reagents were 
purchased from WelGENE (Daegu, Korea). The EZ-CyTox Cell Viability assay kit was purchased from Daeil Lab Service Co. (Seoul, Korea). Formaldehyde, crystal violet and DMSO were obtained from Sigma (St. Louis, MO, USA). The EzWay Annexin V-FITC apoptosis detection kit was purchased from KOMA Biotech (Seoul, Korea). Xpert protease inhibitor cocktail was purchased from GenDEPOT (Barker, TX, USA). Primary antibodies against Bcl2, Bax and $\beta$-actin were purchased by Santa Cruz Biotechnology (Santa Cruz, CA, USA), and horseradish peroxidase (HRP)-conjugated secondary antibody was obtained from Jackson Immuno Research laboratories, Inc. (West Grove, PA, USA). The enhanced chemiluminescence (ECL) kit was obtained from Advansta Inc. (Advansta, CA, USA).

\subsection{Extraction and Isolation}

The air-dried barks of $J$. sinensis $(18 \mathrm{~kg})$ were extracted with $\mathrm{MeOH}(25 \mathrm{~L} \times 4)$ for $24 \mathrm{~h}$ at room temperature. The solvent was evaporated in vacuo to provide a concentrated $\mathrm{MeOH}$ extract $(1.6 \mathrm{~kg})$, which was then diluted with distilled water $(1.2 \mathrm{~L})$ to afford an aqueous methanolic solution. The aqueous solution was sequentially partitioned with $n$-hexane $(3 \mathrm{~L} \times 3)$, EtOAc $(2 \mathrm{~L} \times 3)$, and $n$-BuOH $(3 \mathrm{~L} \times 3)$ to afford the following fractions: $n$-hexane $(170 \mathrm{~g})$, EtOAc $(755 \mathrm{~g})$, and $n$-BuOH-soluble $(414 \mathrm{~g})$ fractions. The partial EtOAc fraction $(350 \mathrm{~g})$ was subjected to silica gel column chromatography (CC) $\left(\mathrm{CHCl}_{3}-\mathrm{MeOH}, 99: 1\right.$ to 2:1, v/v) to yield ten fractions (E01-E10). Fraction E09 (66.84 g) was recrystallized using $\mathrm{MeOH}$ to afford $\mathbf{1 1}(10 \mathrm{~g})$. Fraction E02 $(6.5 \mathrm{~g})$ was applied to silica gel CC $\left(\mathrm{CHCl}_{3}\right.$-acetone, 99.5:0.5 to 98:2, $\left.v / v\right)$, leading to fifteen sub-fractions (E0201-E0215). Among them, sub-fraction E0205 (99.5:0.5, $50 \mathrm{mg})$, E0206 (99.5:0.5, $45 \mathrm{mg})$, and E0214 (98.5:1.5, $598.78 \mathrm{mg})$ were identified as 1 (40 mg), $2(50 \mathrm{mg})$, and $6(500 \mathrm{mg})$, respectively. Sub-fraction E0215 (2.3 g) was subjected to silica gel CC $\left(\mathrm{CHCl}_{3}\right.$-acetone, $99: 1$ to $\left.98: 2, v / v\right)$ and was further purified by RP-C ${ }_{18} \mathrm{CC}$ (MeOH-water, 1:1 to 2:1, v/v) to afford $3(7 \mathrm{mg})$. Fraction E0210 $(166 \mathrm{mg})$ was purified by RP-C ${ }_{18} \mathrm{CC}$ $\left(\mathrm{CH}_{3} \mathrm{CN}\right.$-water, 1:9 to 1:1, v/v) to furnish $4(4 \mathrm{mg})$. Fraction E07 $(56 \mathrm{~g})$ was applied to silica gel CC $\left(\mathrm{CHCl}_{3}-\mathrm{MeOH}, 99: 1\right.$ to 1:1, v/v), leading to twelve sub-fractions (E0701-F0712). Sub-fraction E0711 (7.6 g) was subjected to RP-C ${ }_{18}$ CC (MeOH-water, 1:3 to 1:1, v/v) and Sephadex LH-20 CC (100\% $\mathrm{MeOH})$, affording $5(8 \mathrm{mg}), \mathbf{1 3}(7 \mathrm{mg})$, and $\mathbf{1 7}(2 \mathrm{mg})$. The combined sub-fractions, E0707 and E0708 $(17 \mathrm{~g})$, were further purified by silica gel CC $\left(\mathrm{CHCl}_{3}\right.$-acetone, $99: 1$ to $\left.1: 1, v / v\right)$ to afford $9(116 \mathrm{mg}), \mathbf{1 0}$ $(8 \mathrm{mg})$, and $16(70 \mathrm{mg})$. Sub-fraction E0710 $(11 \mathrm{~g})$ was subjected to silica gel $\mathrm{CC}\left(\mathrm{CHCl}_{3}-\mathrm{MeOH}, 99: 1\right.$ to 1:1, v/v) to obtain $12(9 \mathrm{mg})$. The combined fractions, E04 and E05 (4.6 g) was applied to silica gel CC ( $\mathrm{CHCl}_{3}$-acetone, 99:1 to 1:1, v/v) leading to 15 sub-fractions (E0401-F0415) and $\mathbf{7}(36 \mathrm{mg})$. Sub-fraction E0409 (161 mg) was further purified by RP- $\mathrm{C}_{18} \mathrm{CC}(\mathrm{MeOH}$-water, 1:1 to 3:1, v/v), affording 14 (2 mg). The BuOH fraction (414 g) was subjected to silica gel $\mathrm{CC}\left(\mathrm{CH}_{2} \mathrm{Cl}_{2}-\mathrm{MeOH}, 98: 2\right.$ to 1:1, $\left.v / v\right)$ to yield 13 fractions (B01-B13). The combined sub-fractions, B06, B07, and B08 (6.2 g), were applied to RP-C 18 $\mathrm{CC}(\mathrm{MeOH}$-water, 1:4 to 1:2, v/v) providing eighteen sub-fractions (B0601-B0618) and 8 (70 mg). The combined sub-fractions, $\mathrm{B} 0609$ and $\mathrm{B} 0610(811 \mathrm{mg})$, were purified by silica gel $\mathrm{CC}\left(\mathrm{CH}_{2} \mathrm{Cl}_{2}-\mathrm{MeOH}\right.$, 49:1 to $1: 1, v / v)$ to obtain $15(100 \mathrm{mg})$.

8-Hydroxy-2-methoxy-1,4-naphthoquinone (1). Light brown needle-like crystals. ${ }^{1} \mathrm{H}-\mathrm{NMR}\left(\mathrm{CDCl}_{3}\right.$, $400 \mathrm{MHz}) \delta 11.75(1 \mathrm{H}, \mathrm{s}, \mathrm{OH}), 7.63(2 \mathrm{H}, \mathrm{dd}, J=2.8,6.4 \mathrm{~Hz}$, overlapped H-5 and H-6), $7.25(1 \mathrm{H}$, $\mathrm{dd}, J=2.8,6.4 \mathrm{~Hz}, \mathrm{H}-7), 6.16(1 \mathrm{H}, \mathrm{s}, \mathrm{H}-3), 3.92\left(3 \mathrm{H}, \mathrm{s}, \mathrm{OCH}_{3}\right) ;{ }^{1} \mathrm{H}-\mathrm{NMR}(\mathrm{DMSO}, 400 \mathrm{MHz}) \delta 11.57(1 \mathrm{H}$, $\mathrm{s}, \mathrm{OH}), 7.74(1 \mathrm{H}, \mathrm{t}, J=7.7 \mathrm{~Hz}, \mathrm{H}-6), 7.50(1 \mathrm{H}, \mathrm{dd}, J=7.7,1.0 \mathrm{~Hz}, \mathrm{H}-5), 7.25(1 \mathrm{H}, \mathrm{dd}, J=7.7,1.0 \mathrm{~Hz}, \mathrm{H}-7)$, $6.34(1 \mathrm{H}, \mathrm{s}, \mathrm{H}-3), 3.87\left(3 \mathrm{H}, \mathrm{s}, \mathrm{OCH}_{3}\right) ;{ }^{13} \mathrm{C}-\mathrm{NMR}\left(\mathrm{CDCl}_{3}\right) \delta 184.9(\mathrm{C}-1), 183.9(\mathrm{C}-4), 162.0(\mathrm{C}-8), 160.1$ (C-2), 137.2 (C-6), 132.1 (C-10), 123.9 (C-7), 118.9 (C-5), 114.3 (C-9), 110.5 (C-3), $56.6\left(\mathrm{OCH}_{3}\right)$; HRESIMS $m / z 204.0421[\mathrm{M}]^{+}$(calcd. for $\mathrm{C}_{11} \mathrm{H}_{8} \mathrm{O}_{4}{ }^{+}, 204.0423$ ).

5-Hydroxy-2-methoxy-1,4-naphthoquinone (2). Light brown powder. ${ }^{1} \mathrm{H}-\mathrm{NMR}\left(\mathrm{CDCl}_{3}, 400 \mathrm{MHz}\right) \delta 12.23$ $(1 \mathrm{H}, \mathrm{s}, \mathrm{OH}), 7.68(1 \mathrm{H}, \mathrm{dd}, J=1.2,8.1 \mathrm{~Hz}, \mathrm{H}-8), 7.59(1 \mathrm{H}, \mathrm{t}, J=8.1 \mathrm{~Hz}, \mathrm{H}-7), 7.28(1 \mathrm{H}, \mathrm{dd}, J=1.2,8.1 \mathrm{~Hz}$, H-6), $6.11(1 \mathrm{H}, \mathrm{s}, \mathrm{H}-3), 3.93\left(3 \mathrm{H}, \mathrm{s}, \mathrm{OCH}_{3}\right) ;{ }^{13} \mathrm{C}-\mathrm{NMR}\left(\mathrm{CDCl}_{3}\right) \delta 190.8$ (C-4), $179.4(\mathrm{C}-1), 161.1$ (C-2), 161.1 (C-5), 135.5 (C-7), 131.1 (C-9), 125.2 (C-6), 119.6 (C-8), 114.2 (C-10), 109.5 (C-3), $56.6\left(\mathrm{OCH}_{3}\right)$; HRESIMS $m / z 204.0421[\mathrm{M}]^{+}$(calcd. for $\mathrm{C}_{11} \mathrm{H}_{8} \mathrm{O}_{4}{ }^{+}, 204.0423$ ). 
(4S)-Isosclerone (3). Amorphous solid. $\mathrm{CD}\left(\mathrm{MeOH}, c=5.62 \times 10^{-3} \mathrm{M}\right) \Delta \varepsilon(\mathrm{nm}):-27.6(255),+10.7$ (203) [16].

(4S)-5-Hydroxy-4-methoxy- $\alpha$-tetralone (4). Amorphous powder. $\mathrm{CD}\left(\mathrm{MeOH}, c=5.20 \times 10^{-3} \mathrm{M}\right) \Delta \varepsilon(\mathrm{nm})$ : $-0.8(345),+10.8$ (230) [16].

(2S)-Sakuranetin (6). Pale yellow powder. $\mathrm{CD}\left(\mathrm{MeOH}, c=3.5 \times 10^{-3} \mathrm{M}\right)+1.5$ (334), -23.6 (293) [19,20].

(2S)-Naringenin (7). Pale brown powder. CD (MeOH, $\left.c=3.7 \times 10^{-3} \mathrm{M}\right)+2.0(331),-21.6(291)[19,20]$.

(2R)-Sakuranin (8). White amorphous powder. $\mathrm{CD}\left(\mathrm{MeOH}, c=3.3 \times 10^{-3} \mathrm{M}\right)-1.9(333),+9.2$ (290) $[19,20]$.

(-)-Taxifolin 3-O- $\alpha$-L-arabinofuranoside (13). Amorphous solid. $[\alpha]_{\mathrm{D}}^{24}-26.7(c 0.1, \mathrm{MeOH})[40]$.

(erythro)-1-(4-Hydroxyphenyl)-1,2,3-propanetriol (14). Brown needle. $[\alpha]_{\mathrm{D}}^{24}-48.2$ (c 0.05, MeOH) [41].

(7S,8S)-Cilicione b (16). Yellow solid. $[\alpha]_{\mathrm{D}}^{24}+16.0$ ( 0 0.1, MeOH) [42].

(2S)-1,2-Butanediol (17). Light yellow solid. $[\alpha]_{\mathrm{D}}^{24}+7.8$ (c 0.1, EtOH) [29].

\subsection{Cell Culture}

A549 (human non-small cell lung carcinoma cell), HCT116 (human colorectal carcinoma cell), SNU423 (human hepatocellular carcinoma cell), MCF7 (human breast adenocarcinoma cell), SH-SY5Y (human neuroblastoma cell), and HeLa (human cervical adenocarcinoma cell) were obtained from the Korean Cell Line Bank (Seoul, Korea). A549, HCT116, SNU423, and HeLa cells were maintained in the RPMI-1640 medium containing $10 \%$ FBS, $1 \%$ penicillin/streptomycin at $37^{\circ} \mathrm{C}$ under $5 \% \mathrm{CO}_{2}$ conditions. MCF7 and SH-SY5Y cells were cultured in the DMEM supplemented with $10 \%$ FBS and $1 \%$ penicillin/streptomycin at $37^{\circ} \mathrm{C}$ under $5 \% \mathrm{CO}_{2}$ conditions.

\subsection{Cell Viability Assay}

Cells were cultured on 96-well plates at a density of $5 \times 10^{4}$ cells $/ \mathrm{mL}$ and treated with compounds at the indicated concentrations. After $24 \mathrm{~h}$ of incubation, cell viability was analyzed according to the manufacturer's instructions using the EZ-CyTox Cell Viability assay kit. Briefly, $10 \mu \mathrm{L}$ of kit solution was added to each well for additional $4 \mathrm{~h}$ incubation. Absorbance was detected at $450 \mathrm{~nm}$ using a VERSA max microplate reader (Molecular Devices, Sunnyvale, CA, USA) and used to calculate the percentage of viable cells compared to the untreated cells. Results were expressed as cell viability $(\%)=($ mean absorbency in test wells $/$ mean absorbency in control wells $) \times 100$. Cytotoxicity was expressed as the concentration of inhibiting cell growth by $50 \%\left(\mathrm{IC}_{50}\right.$ value).

\subsection{Colony Formation Assay}

Cells were treated with compounds $\mathbf{1}$ and $\mathbf{2}$ at indicated concentrations for two weeks. The medium was changed every three days by the treatment with compounds $\mathbf{1}$ and $\mathbf{2}$. After that, the supernatant was thrown away, and the cells were washed three times with phosphate-buffered saline (PBS). The cells were fixed with $4 \%$ formaldehyde for $30 \mathrm{~min}$ and stained with $0.1 \%$ crystal violet for $30 \mathrm{~min}$. Colonies were photographed, and the number of colonies was counted using Image $\mathrm{J}$ (National Institutes of Health, Bethesda, MD, USA) from three independent experiments.

\subsection{Flow Cytometry Analysis}

Annexin V positive MCF7 cells were detected using an EzWay Annexin V-FITC apoptosis detection kit according to the manufacturer's protocol. Briefly, MCF7 cells were seeded and incubated with the indicated concentration of compounds 1 and 2 for $24 \mathrm{~h}$. The cells were harvested, washed three times with PBS, and incubated with $1 \times$ Binding Buffer. Then, the cells were incubated with $1.25 \mu \mathrm{L}$ of Annexin V-FITC and $10 \mu \mathrm{L}$ of propidium iodide (PI) at room temperature for $15 \mathrm{~min}$ in the dark. 
The samples were analyzed using a FACScan flow cytometer (Becton Dickinson, San Jose, CA, USA). The apoptosis percentage was calculated as the number of PI positive and Annexin-V positive cells divided by the total number of cells. The experiments were repeated three times independently.

\subsection{Western Blotting}

Cells were washed with PBS and lysed in lysis buffer $(20 \mathrm{mM}$ HEPES, pH 7.5, $150 \mathrm{mM} \mathrm{NaCl}, 10 \%$ glycerol, $50 \mathrm{mM}$ EDTA, 1\% Triton X-100) containing a protease inhibitor cocktail at $4{ }^{\circ} \mathrm{C}$ for $20 \mathrm{~min}$. After centrifugation at 12,000 rpm for $15 \mathrm{~min}$, the supernatants were collected. Protein concentration was determined using the Bradford protein assay (Bio-Rad, Hercules, CA, USA). Equal amounts of proteins were subjected to a $12 \%$ sodium dodecyl sulfate-polyacrylamide gel electrophoresis (SDS-PAGE) and transferred to a nitrocellulose membrane. The membranes were then blocked with $5 \%$ skim milk for $1 \mathrm{~h}$ and incubated with primary antibody. After washing, the membranes were incubated with a horseradish peroxidase (HRP)-conjugated secondary antibody for $1 \mathrm{~h}$. Proteins bands were visualized using an enhanced chemiluminescence (ECL) system.

\subsection{Statistical Analysis}

All the data are presented as the mean \pm SD and are representative of at least three independent experiments. Comparisons between the two groups were analyzed by Student's t-test. A $p$ value of less than 0.05 was considered to be statistically significant.

\section{Conclusions}

The leaves and (or) twigs of J. sinensis have usually been subjected to phytochemical and biological studies previously; however, this is the first report of the phytochemical study on the bark of this plant. In this study, bioassay-guided fractionation of an ethyl acetate-soluble fraction of the bark of $J$. sinensis using the A549 cell line, led to the isolation of 17 phenolic compounds 1-17, which were found in this plant for the first time. Moreover, 14 and 16 have never been isolated from the family Juglandaceae. This study suggests that compounds $\mathbf{1}$ and $\mathbf{2}$ are the main compounds responsible for the biological activity for the bark extract of $J$. sinensis. The most active compound $\mathbf{1}$ is a potential candidate for antitumor drug based on its effective cytotoxic and apoptotic activities.

Supplementary Materials: Supplementary materials can be accessed at: http://www.mdpi.com/1420-3049/21/ $1 / 120 /$ s1.

Acknowledgments: This work was supported by the National Research Foundation of Korea (NRF) grant funded by the Korea government (MSIP) (No. NRF-2013R1A2A2A01067336) and a grant from Ewha Womans University Research Grant of 2015 to E.K.S. and by a grant from the Next-Generation BioGreen 21 Program (SSAC, grant \#: PJ01116601), Rural Development Administration, Republic of Korea to H.H.J.

Author Contributions: Yoo Jin Lee and Jun Cui mainly performed experiments, analyzed the data, and drafted the manuscript. Jun Lee designed the experiments, analyzed the data, and drafted the manuscript. Ah-Reum Han and Eun Byul Lee analyzed the data and assisted the revision of the manuscript. Eun Kyoung Seo and Ho Hee Jang directed the entire research and drafted the manuscript. All the authors read and approved the final manuscript for submission.

Conflicts of Interest: The authors declare no conflict of interest.

\section{References and Notes}

1. Yang, H.; Cho, H.-J.; Sim, S.H.; Chung, Y.K.; Kim, D.-D.; Sung, S.H.; Kim, J.; Kim, Y.C. Cytotoxic terpenoids from Juglans sinensis leaves and twigs. Bioorg. Med. Chem. Lett. 2012, 22, 2079-2083. [CrossRef] [PubMed]

2. Yang, H.; Sung, S.H.; Kim, J.; Kim, Y.C. Neuroprotective diarylheptanoids from the leaves and twigs of Juglans sinensis against glutamate-induced toxicity in HT22 cells. Planta Med. 2011, 77, 841-845. [CrossRef] [PubMed]

3. Yang, H.; Jeong, E.J.; Kim, J.W.; Sung, S.H.; Kim, Y.C. Antiproliferative triterpenes from the leaves and twigs of Juglans sinensis on HSC-T6 Cells. J. Nat. Prod. 2011, 74, 751-756. [CrossRef] [PubMed] 
4. An, R.-B.; Kim, H.-C.; Tian, Y.-H.; Kim, Y.-C. Free radical scavenging and hepatoprotective constituents from the leaves of Juglans sinensis. Arch. Pharm. Res. 2005, 28, 529-533. [CrossRef] [PubMed]

5. Lee, Y.-C.; Kim, S.-H. Immunomodulatory effect of Juglans sinensis, Psoralea corylifolia, cheong-a-hwan extract and cyclosporine A on Th1 (IFN- $\gamma$ )/Th2 (IL-4) cytokine balance, eosinophil accumulation in a murine model of asthma. Phytochem. Lett. 2008, 1, 6-10. [CrossRef]

6. Yang, H.; Sung, S.H.; Kim, Y.C. The ethanolic extract of Juglans sinensis leaves and twigs attenuates CCl4-induced hepatic oxidative stress in rats. Pharmacogn. Mag. 2015, 11, 533-539. [PubMed]

7. Ahn, C.B.; Song, C.H.; Kim, W.H.; Kim, Y.K. Effects of Juglans sinensis Dode extract and antioxidant on mercury chloride-induced acute renal failure in rabbits. J. Ethnopharmacol. 2002, 82, 45-49. [CrossRef]

8. Hasan, T.N.; B, L.G.; Shafi, G.; Al-Hazzani, A.A.; Alshatwi, A.A. Anti-proliferative effects of organic extracts from root bark of Juglans regia L. (RBJR) on MDA-MB-231 human breast cancer cells: Role of Bcl-2/Bax, caspases and Tp53. Asian Pac. J. Cancer Prev. 2011, 12, 525-530. [PubMed]

9. Negi, A.S.; Luqman, S.; Srivastava, S.; Krishna, V.; Gupta, N.; Darokar, M.P. Antiproliferative and antioxidant activities of Juglans regia fruit extracts. Pharm. Biol. 2011, 49, 669-673. [CrossRef] [PubMed]

10. Carvalho, M.; Ferreira, P.J.; Mendes, V.S.; Silva, R.; Pereira, J.A.; Jerónimo, C.; Silva, B.M. Human cancer cell antiproliferative and antioxidant activities of Juglans regia L. Food Chem. Toxicol. 2010, 48, 441-447. [CrossRef] [PubMed]

11. Park, G.; Kim, H.G.; Hong, S.P.; Kim, S.Y.; Oh, M.S. Walnuts (seeds of Juglandis sinensis L.) protect human epidermal keratinocytes against UVB-induced mitochondria-mediated apoptosis through upregulation of ROS elimination pathways. Skin Pharmacol. Physiol. 2014, 27, 132-140. [CrossRef] [PubMed]

12. Boisvert, L.; Brassard, P. Regiospecific addition of monooxygenated dienes to halo quinones. J. Org. Chem. 1988, 53, 4052-4059. [CrossRef]

13. Zhou, Y.; Yang, B.; Jiang, Y.; Liu, Z.; Liu, Y.; Wang, X.; Kuang, H. Studies on Cytotoxic Activity against HepG-2 Cells of Naphthoquinones from Green Walnut Husks of Juglans mandshurica Maxim. Molecules 2015, 20, 15572-15588. [CrossRef] [PubMed]

14. Ma, L.; Lin, J.; Li, Q.; Zhang, L.; Chen, A. Antifungal constituents from the husk of Carya cathayensis. Linye Kexue 2009, 45, 90-94.

15. Kokubun, T.; Veitch, N.C.; Bridge, P.D.; Simmonds, M.S.J. Dihydroisocoumarins and a tetralone from Cytospora eucalypticola. Phytochemistry 2003, 62, 779-782. [CrossRef]

16. Machida, K.; Matsuoka, E.; Kasahara, T.; Kikuchi, M. Studies on the constituents of Juglans species. I. Structure determination of (4S)- and (4R)-4-hydroxy- $\alpha$-tetralone derivatives from the fruit of Juglans mandshurica Maxim. Var. sieboldiana Makino. Chem. Pharm. Bull. 2005, 53, 934-937. [CrossRef] [PubMed]

17. Yu, H.-Y.; Li, X.; Meng, F.-Y.; Pi, H.-F.; Zhang, P.; Ruan, H.-L. Naphthoquinones from the root barks of Juglans cathayensis Dode. J. Asian Nat. Prod. Res. 2011, 13, 581-587. [CrossRef]

18. Jerz, G.; Waibel, R.; Achenbach, H. Cyclohexanoid protoflavanones from the stem-bark and roots of Ongokea gore. Phytochemistry 2005, 66, 1698-1706. [CrossRef] [PubMed]

19. Gaffield, W. Circular dichroism, optical rotatory dispersion, and absolute configuration of flavanones, 3-hydroxyflavanones, and their glycosides. Determination of aglycone chirality in flavanone glycosides. Tetrahedron 1970, 26, 4093-4108. [CrossRef]

20. Slade, D.; Ferreira, D.; Marais, J.P.J. Circular dichroism, a powerful tool for the assessment of absolute configuration of flavonoids. Phytochemistry 2005, 66, 2177-2215. [CrossRef] [PubMed]

21. Bertelli, D.; Papotti, G.; Bortolotti, L.; Marcazzan, G.L.; Plessi, M. ${ }^{1} \mathrm{H}-\mathrm{NMR}$ simultaneous identification of health-relevant compounds in propolis extracts. Phytochem. Anal. 2011, 23, 260-266. [CrossRef] [PubMed]

22. Zhang, X.F.; Hung, T.M.; Phuong, P.T.; Ngoc, T.M.; Min, B.-S.; Song, K.-S.; Seong, Y.H.; Bae, K.H. Anti-inflammatory activity of flavonoids from Populus davidiana. Arch. Pharm. Res. 2006, 29, 1102-1108. [CrossRef] [PubMed]

23. Miyazawa, M.; Hisama, M. Antimutagenic activity flavonoids from Chrysanthemum morifolium. Biosci. Biotechnol. Biochem. 2003, 67, 2091-2099. [CrossRef] [PubMed]

24. Jang, D.S.; Kim, J.M.; Lee, Y.M.; Yoo, J.L.; Kim, Y.S.; Kim, J.-H.; Kim, J.S. Flavonols from Houttuynia cordata with protein glycation and aldose reductase inhibitory activity. Nat. Prod. Res. 2006, 12, 210-213.

25. Wu, Z.; Li, R. Chemical constituents from the roots of Rhododendron spiciferum. Tianran Chanwu Yanjiu Yu Kaifa 2011, 23, 253-257. 
26. Jang, K.C.; Lee, J.H.; Kim, S.C.; Song, E.Y.; Ro, N.Y.; Moon, D.Y.; Um, Y.C.; Park, K.H. Antibacterial and radical scavenging activities of 1-C-( $p$-hydroxyphenyl)-glycerol from Trichosanthes kirilowii. J. Appl. Biol. Chem. 2007, 50, 17-21.

27. Machida, K.; Yogiashi, Y.; Matsuda, S.; Suzuki, A.; Kikuchi, M. A new phenolic glycoside syringate from the bark of Juglans mandshurica MAXIM. var. sieboldiana MAKINO. J. Nat. Med. 2009, 63, 220-222. [CrossRef] [PubMed]

28. Ahmed, B.; Al-Howiriny, T.A. Two new hydroxy chalcone derivatives from Thymus cilicicus. Z. Naturforsch. 2007, 62b, 121-124. [CrossRef]

29. Poppe, L.; Novak, L.; Kajtar-Peredy, M.; Szantay, C. Lipase-catalyzed enantiomer selective hydrolysis of 1,2-diol diacetates. Tetrahedron 1993, 4, 2211-2217. [CrossRef]

30. DeSantis, C.; Ma, J.; Bryan, L.; Jemal, A. Breast cancer statistics, 2013. CA Cancer J. Clin. 2014, 64, 52-62. [CrossRef] [PubMed]

31. Kim, S.H.; Lee, K.S.; Son, J.K.; Je, G.H.; Lee, J.S.; Lee, C.H.; Cheong, C.J. Cytotoxic compounds from the roots of Juglans mandshurica. J. Nat. Prod. 1998, 61, 643-645. [CrossRef] [PubMed]

32. Li, S.; Shi, Y.; Shang, X.Y.; Cui, B.S.; Yuan, Y.; Chen, X.G.; Yang, Y.C.; Shi, J.G. Triterpenoids from the roots of Pterospermum heterophyllum Hance. J. Asian Nat. Prod. Res. 2009, 11, 652-657. [CrossRef] [PubMed]

33. Pelageev, D.N.; Dyshlovoy, S.A.; Pokhilo, N.D.; Denisenko, V.A.; Borisova, K.L.; Keller-von Amsberg, G.; Bokemeyer, C.; Fedorov, S.N.; Honecker, F.; Anufriev, V.P. Quinone-carbohydrate nonglucoside conjugates as a new type of cytotoxic agents: Synthesis and determination of in vitro activity. Eur. J. Med. Chem. 2014, 77, 139-144. [CrossRef] [PubMed]

34. Ong, J.Y.H.; Yong, P.V.C.; Lim, Y.M.; Ho, A.S.H. 2-Methoxy-1,4-naphthoquinone (MNQ) induces apoptosis of A549 lung adenocarcinoma cells via oxidation-triggered JNK and p38 MAPK signaling pathways. Life Sci. 2015, 135, 158-164. [CrossRef] [PubMed]

35. Kroemer, G.; Galluzzi, L.; Vandenabeele, P.; Abrams, J.; Alnemri, E.S.; Baehrecke, E.H.; Blagosklonny, M.V.; El-Deiry, W.S.; Golstein, P.; Green, D.R.; et al. Classification of cell death: Recommendations of the Nomenclature Committee on Cell Death 2009. Cell Death Differ. 2009, 16, 3-11. [CrossRef] [PubMed]

36. Galluzzi, L.; Vitale, I.; Abrams, J.M.; Alnemri, E.S.; Baehrecke, E.H.; Blagosklonny, M.V.; Dawson, T.M.; Dawson, V.L.; El-Deiry, W.S.; Fulda, S.; et al. Molecular definitions of cell death subroutines: Recommendations of the Nomenclature Committee on Cell Death 2012. Cell Death Differ. 2012, 19, 107-120. [CrossRef] [PubMed]

37. Pan, G.; O’Rourke, K.; Chinnaiyan, A.M.; Gentz, R.; Ebner, R.; Ni, J.; Dixit, V.M. The receptor for the cytotoxic ligand TRAIL. Science 1997, 276, 111-113. [CrossRef] [PubMed]

38. Zapata, J.M.; Pawlowski, K.; Haas, E.; Ware, C.F.; Godzik, A.; Reed, J.C. A diverse family of proteins containing tumor necrosis factor receptor-associated factor domains. J. Biol. Chem. 2001, 276, 24242-24252. [CrossRef] [PubMed]

39. Yip, K.W.; Reed, J.C. Bcl-2 family proteins and cancer. Oncogene 2008, 27, 6398-6406. [CrossRef] [PubMed]

40. Ishimaru, K.; Omoto, T.; Asai, I.; Ezaki, K.; Shimomura, K. Taxifolin 3-arabinoside from Fragaria xananassa. Phytochemistry 1995, 40, 345-347. [CrossRef]

41. Li, Y.-L.; Gao, Y.-X.; Jin, H.-Z.; Shan, L.; Chang, W.-L.; Yang, X.-W.; Zeng, H.-W.; Wang, N.; Steinmetz, A.; Zang, W.-D. Chemical constituents of Abies fabri. Phytochemistry 2015, 117, 135-143. [CrossRef] [PubMed]

42. Kim, K.H.; Moon, E.J.; Choi, S.U.; Kim, S.Y.; Lee, K.R. Polyphenols from the bark of Rhus verniciflua and their biological evaluation on antitumor and anti-inflammatory activities. Phytochemistry 2013, 92, 113-121. [CrossRef] [PubMed]

Sample Availability: Not available.

(C) 2016 by the authors; licensee MDPI, Basel, Switzerland. This article is an open access article distributed under the terms and conditions of the Creative Commons by Attribution (CC-BY) license (http://creativecommons.org/licenses/by/4.0/). 